\title{
Promising Antipoverty Strategies for Families
}

\author{
Maria Cancian \\ University of Wisconsin-Madison \\ Daniel R. Meyer \\ University of Wisconsin-Madison \\ Deborah Reed \\ Mathematica Policy Research
}

Paper Prepared for

The Georgetown University and Urban Institute

Conference on Reducing Poverty and Economic Distress after ARRA

January 15, 2010

May, 2010 
Copyright (C) March 2010. The Urban Institute. Permission is granted for reproduction of this file, with attribution to the Urban Institute.

The Urban Institute is a nonprofit, nonpartisan policy research and educational organization that examines the social, economic, and governance problems facing the nation. The views expressed are those of the authors and should not be attributed to the Urban Institute, its trustees, or its funders.

We thank Sheldon Danziger and Jennifer Noyes for helpful suggestions, Eunhee Han for research assistance, and Deborah Johnson for editorial assistance. 


\section{Contents}

Introduction

The Context: American Families Are Increasingly Diverse, Dynamic, and Dependent on Labor Market Earnings to Avoid Poverty and Economic Distress

Children Are Less Likely to Live in Families with Both Parents and More Likely to Rely on Their Mothers' Earnings to Avoid Poverty

The Recession Has Had Differential Effects on Employment by Family Type and Race

Implications for Policy: Supporting Working Resident and Nonresident Parents

Supporting Parents' Efforts to Balance Work and Family Responsibilities Will Help Reduce

Poverty and Economic Distress

Enforcing and Supporting Nonresident Parents' Contributions to Their Children Will Help

Reduce Poverty and Economic Distress

There Is Little Evidence That Policies Designed to Reduce the Proportion of Children Living in Single-Parent Families Can Substantially Reduce Poverty and Economic Distress

Conclusions

References

Notes 


\section{Introduction}

A large percentage of poor children live with just one parent, usually their mother, and single-parent families are more vulnerable to economic downturns than are two-parent families. Living arrangements also affect the optimal design of policies related to income support and child support. In this paper, we briefly review changes in family structure, the relationship between family structure and employment, and early evidence on differential impacts of the recession on families.

We then focus on policies that are essential to reducing poverty in the context of the current work-based safety net, in which low-income families with children rely increasingly on mothers' earnings. We argue that economically vulnerable families will benefit the most from policies that support resident parents' efforts to balance work and caretaking, and that support and enforce nonresident parents' contributions.

The recent changes in the American Recovery and Reinvestment Act (ARRA) are an important starting point for antipoverty policy supporting families, but most were time limited. While the recession highlighted the urgency of many of these programs, the needs they address are longstanding and require a sustained response.

\section{The Context: American Families Are Increasingly Diverse, Dynamic, and Dependent on Labor Market Earnings to Avoid Poverty and Economic Distress}

\section{Children Are Less Likely to Live in Families with Both Parents and More Likely to Rely on Their Mothers' Earnings to Avoid Poverty}

The American family has changed dramatically in recent decades, creating both challenges and opportunities for antipoverty policies. The growing proportion of children raised in single-mother families means more children are at increased risk of economic deprivation, while the related increase in mothers' work and earnings have helped more children avoid poverty (Cancian and Reed 2009).

Decisions about marriage, childbearing, and work are increasingly disconnected (Edin and Kefalas 2005; Ellwood and Jencks 2004). Forty percent of children were born to unmarried mothers in 2007 (Hamilton, Martin, and Ventura 2009); while their parents are often romantically involved at the time of the birth, most nonmarital relationships do not last (Fragile Families 2007). Further, many children born to married parents will see their parents divorce before the children turn 16. Thus, the majority of American children will live at least some part of their childhood in a family that does not include both biological parents.

While children are increasingly likely to experience family disruption, the growth in employment among married and unmarried mothers has altered the consequences of family structure for children's access to resources. Fewer children have a parent at home full time, regardless of family structure. Over two-thirds of married women with preschool-age children worked during 2006 (Cancian and Reed 2009). Low-wage workers-even in married-couple families-face particularly difficult choices in balancing their responsibilities as parents and workers. At the same time, single mothers are increasingly likely to work, shouldering the primary responsibility for providing both care and financial support for their children. Coinciding with the implementation of the 1996 federal welfare reform, employment rates for single mothers increased 
substantially; over three-quarters of single mothers of preschool-age children now work for pay at least part of the year (Cancian and Reed 2009).

In the current policy context, with very limited cash income supports available to nonworkers, poverty status largely depends on the number of working adults in the household, their hours of work and wage rates, and the number of children (and adults) they have to support. Declines in marriage have reduced the number of adults directly available to support the children, but declines in the number of children per woman have reduced resource needs, and increases in mothers' work have increased resources (Cancian and Reed 2009). Overall, the combination of these trends means that poverty rates for children have grown since the late 1960s and remain stubbornly high.

Earnings declines for less-educated men and the persistently lower average earnings of women have made it harder for families to make ends meet. Even though the earnings of men with low education have fallen in recent decades in absolute terms, and relative to women, male earnings remain higher than female earnings on average (Danziger and Ratner forthcoming). More specifically, in 2007, the median earnings for employed high school graduates (without college educations) were about $\$ 33,000$ (in 2008 dollars) for white men and $\$ 27,000$ for black and Hispanic men; they were $\$ 21,000$ for white and Hispanic women and $\$ 19,000$ for black women. Thus, singlemother families are at a disadvantage both because they are more likely to have only one potential worker, and because of the relatively lower wages of women.

\section{The Recession Has Had Differential Effects on Employment by Family Type and Race}

Children in families largely dependent on a single earner are also more vulnerable to macroeconomic fluctuations. Increases in married mothers' employment helped reduce the vulnerability of many families when one parent became unemployed but the other kept his or her job. Yet, families already dependent on two workers cannot make up for a layoff or decline in earnings by adding a second worker. Moreover, single-parent families have fewer options, and the lowest income families are now more vulnerable to an economic downturn given that the safety net provides little income support for families with no workers. While Aid to Families with Dependent Children provided an income floor for most single-mother families, Temporary Assistance for Needy Families (TANF) provides a less secure safety net because it is not an entitlement, and, given block grant funding, federal funding is not inherently countercyclical. The earned income tax credit (EITC) is an important income source for low-income families, but because it is tied to the level of earnings, for many, declines in earnings also lead to reductions in the EITC.

The unemployment rate peaked in October 2009 at 10.2 percent. ${ }^{1}$ More detailed unemployment data available for 2008 suggest that patterns of unemployment during the current recession compounded the vulnerability of many families. Unemployment rates rose more quickly in absolute magnitude for unmarried mothers than for married mothers, for those with younger children than for those with older children, and for blacks than for whites. Unemployment rates were generally lower, but increased as much or more, for fathers than for mothers. ${ }^{2}$ 


\section{Implications for Policy: Supporting Working Resident and Nonresident Parents}

\section{Supporting Parents' Efforts to Balance Work and Family Responsibilities Will Help Reduce Poverty and Economic Distress}

The United States has adopted an antipoverty strategy that presumes that most adults will work for pay, even if they have young children. If this strategy is to be functional, we need programs and policies that enable working parents to simultaneously meet their responsibilities to their employers and their children. This is particularly critical for single parents, who are generally less likely to be able to rely on another adult for financial or logistical support.

Affordable child care constitutes an essential building block of a work-based antipoverty strategy. But notwithstanding substantial increases in national spending on subsidized care, estimates suggest that only about a third of eligible low-income families were receiving subsidies even before the recession (Mezey, Greenberg, and Schumacher 2002; U.S. Department of Health and Human Services 2005). ARRA provides significant financing for child care and early education, including a $\$ 2$ billion increase in the Child Care and Development Block Grant, and a total of \$2.1 billion for Head Start and Early Head Start (Sherman 2009). ${ }^{3}$ ARRA also substantially reduces the earnings required to qualify for a child tax credit, which may offset child-related work expenses, including child care. States have used ARRA funds to shore up child care programs and, in some cases, adapt to particular challenges associated with the recession. For example, 10 states are using ARRA funds to expand the time during which parents can receive child care subsidies while they search for work; in most states, subsidies are available only while all parents are working or in school. ${ }^{4}$ But, despite ARRA funds, fiscal pressures associated with the recession have led many states to make cuts —at a time when subsidies are critical for many families.

In addition to child care, working parents need workplace policies that recognize their parental responsibilities. Family-friendly workplace policies are an issue for most families and are a critical part of antipoverty policy. Many economically vulnerable families are headed by single parents, who often have sole responsibility for providing care and financial support for their children. Low-income families have very limited resources to buy market alternatives-from child care to prepared meals - that help higher-income workers meet family needs, and are more likely to face challenges that demand more parental time-from long commutes on public transportation to low-quality schools or less safe neighborhoods. Despite their greater needs, low-wage workers are least likely to have even basic workplace benefits such as employer-sponsored health care and paid sick leave (Bureau of Labor Statistics 2007). Moreover, they are less likely to work for employers large enough to be covered by the Family and Medical Leave Act or to have the savings necessary to take advantage of the provision of unpaid leave (Fass 2009). Paid leave programs should be expanded, and the unpaid leave mandate should cover more employers. Policies that require employers to provide paid sick leave should also be considered.

ARRA provides incentives, as part of the Unemployment Insurance (UI) Modernization Act, for states to adopt several policies that would improve the adequacy of the UI system for lowincome working families. To qualify for all available funding, states are required to extend coverage, largely in ways of particular importance to low-income workers with families. As of November 2009, 17 states have extended benefits to individuals seeking only part-time work (more likely to be parents of young children), and 13 states have extended benefits to workers who quit because of compelling family reasons. Four states have added a dependents' allowance to weekly benefits. ${ }^{5}$ These innovations, together with the increases in benefit levels and in the length of eligibility for 
benefits that are also part of ARRA, constitute important improvements in the adequacy of the UI system for low-income families. Problems remain in coverage, however, especially for those working as temporary or contract workers and those who are self-employed or work in the informal economy.

Even when they are working full time, many workers have earnings too low to support a family. Earnings supplements and other work supports are essential elements of a work-focused antipoverty policy; they are necessary for many families if work is to be a feasible route out of poverty, especially for less-educated workers. The earned income tax credit provides a worker with two children a 40 percent supplement to earnings up to about $\$ 12,500$, after which it plateaus and then phases out. The EITC has grown rapidly in the past two decades to become the largest cash or near-cash dedicated antipoverty program (Scholz, Moffitt, and Cowan 2009). ARRA increases the maximum EITC from $\$ 5,028$ to $\$ 5,657$ for families with three or more children and increases the threshold amount for taxpayers filing jointly_making families with incomes up to $\$ 48,250$ eligible for the credit. ${ }^{6}$

In addition to earnings supplements, health insurance is an important support for many lowincome workers, many of whom are not offered employer-sponsored health insurance with family coverage and rely instead on subsidized health insurance for themselves or their children. Medicaid and CHIP expenditures have risen dramatically in recent years, and many states have cut eligibility or benefits in the face of current fiscal pressures. ARRA provides $\$ 87$ million in additional Medicaid funding, with some funds targeting states with particularly high rates of unemployment, and additional funds dependent on states not adopting more restrictive eligibility standards (Kaiser Commission 2009). Of course, the shape of future policies to meet the health insurance needs of low-income families may be fundamentally altered by federal health care reform.

Finally, a safety net that is fundamentally built on work must consider providing jobs of last resort to parents who cannot find work (Mishel et al. 2009). Some TANF programs serve this function-though TANF community service or "workfare" positions are generally not eligible to be supplemented with the EITC, and access to TANF programs is limited. The issues of workforce development and public jobs are addressed by other conference authors.

Many American workers do not earn enough on their own to support a family. And, many of the most economically vulnerable families with children rely on one adult, usually the mother, as the primary provider of both care and income. In this context, an antipoverty strategy built on work requires affordable child care, public and employer policies that provide the benefits and flexibility that allow working parents to meet their responsibilities to family and work, and earnings supplements and other work supports that make it possible for more workers to support a family. ARRA provisions have begun to address these issues; however, in most cases the program and benefit expansions are temporary_-even though the needs are longstanding.

\section{Enforcing and Supporting Nonresident Parents' Contributions to Their Children Will Help Reduce Poverty and Economic Distress}

Most low-income children will spend a substantial part of their childhood in a single-parent family. But even if they work full time, many single parents, especially those with high school degrees or less education, will be unable to support their families on their earnings alone. The child support program can increase the incomes of single-parent families, but current policy is too focused on using child support collections to offset welfare costs. Antipoverty policies must foster a more 
coherent approach to require and enable nonresident parents to financially support their children. A coherent child support system that is effective for low-income children must (1) focus on child support as an income support for families, rather than as a mechanism for government cost recovery, and (2) must include integrated supports to enable nonresident parents to earn enough to provide support. Fathers cannot pay support if they have no income, and families will not benefit if payments are diverted to offset welfare costs.

Traditional child support enforcement policies have been strengthened over recent decades so about half of custodial mothers are legally supposed to receive child support. Nonetheless, while formal child support is an important source of income for many economically vulnerable families, only 41 percent of poor single mothers due child support receive the full amount that the courts have ordered, and 31 percent receive nothing at all.

One key direction for policy change is to refocus child support enforcement on child well-being rather than cost recovery. As we have argued elsewhere (Cancian, Meyer, and Han forthcoming), redesigning the child support system to focus on improving the economic well-being of children requires several changes. Some key reforms are already included in pending legislative proposals, while others are more complex. First steps include changing policy for families receiving TANF assistance so they receive all child support payments made on their behalf without financial penalty, allowing TANF families to keep any past-due child support that is paid, and eliminating efforts to collect Medicaid birthing costs from nonresident fathers, as summarized below.

- Allow TANF families to keep all current child support paid. The Deficit Reduction Act of 2005 provided federal support for states to increase the amount of child support passed through to TANF recipients to up to $\$ 200$ a month for a family with two or more children; an increased pass-through should increase the amount of child support paid, in addition to assuring that support directly benefits children (Cancian, Meyer, and Caspar 2008). However, especially in times of tight state budgets, there are fiscal barriers to states increasing the pass-through, as we discuss below.

- Allow TANF families to keep past-due child support paid. In the past, TANF participants were required to sign away (assign) any past-due child support to the government. Federal policy recently discontinued assignment of past-due support for former TANF participants; only collections while the family is receiving assistance can now be used to offset government costs. Fully eliminating assignment of past-due support would simplify the system, support a coherent focus on child well-being, and be a fairly modest additional change, especially given time-limited TANF participation.

- Eliminate Medicaid birthing cost charges. Some states continue charging nonresident fathers for medical expenses associated with nonmarital births-even when the parents would qualify for Medicaid were they married, and despite no attempt to recoup Medicaid coverage for marital births. Eliminating all birthing charges would be another step toward child support policy focused on supporting children rather than the state.

Variations of all of these proposals are part of the Responsible Fatherhood and Healthy Families Act of 2007 co-sponsored by then-Senator Obama and reintroduced by Senator Bayh in 2009. Together these policy reforms would refocus the child support enforcement system on reducing poverty and economic vulnerability of children. 
While this more focused system would be easier to administer, these reforms would eliminate an important source of revenue for some child support enforcement agencies, as well as potentially undercut support for child support enforcement from those who are primarily concerned with cost recovery. As recently noted by the National Governors Association (2009): "While governors recognize that the ideal goal of the child support program may be to improve a family's economic security, making drastic changes to the child support system without considering the financial stability of the program will not lead to better outcomes for the families and children served." These fiscal concerns must be addressed, but enforcing policy and law with regard to parents' obligations is a general social responsibility, as well as an essential element of antipoverty policy. Child support enforcement should be funded from general revenues, not by diverting money paid by nonresident parents to support their children.

Some critics of child support enforcement as an antipoverty program have argued that the fathers of low-income children are generally resource poor, and unable to provide substantial support. We argue, however, that in the absence of an entitlement to cash assistance and given contemporary expectations that virtually all resident mothers work for pay, as well as care for their children, even disadvantaged fathers should be expected to work in order to provide support their children. This expectation, however, must be balanced by policies that support nonresident fathers' efforts to work and address barriers to employment. Many nonpayers have very low levels of education and poor health (Sorensen and Zibman 2001), and low income and unemployment are the most important factors explaining nonpayment for those with orders (Ha et al. 2008).

Resident mothers' efforts to work are supported by a range of programs designed to help them balance family responsibilities (e.g., child care) as well as make work pay (e.g., the EITC). Resident parents also often have access to benefits tied to their residence with and direct care of children (e.g., subsidized housing, and sometimes health insurance). Nonresident fathers generally do not have the same care responsibilities, but many disadvantaged men nonetheless face limited earnings prospects that must be addressed if these fathers are to regularly pay child support. Key reforms include these three:

- Provide an EITC for nonresident parents paying child support. In addition to proposed expansions of an EITC for childless adults, there are advantages to EITC proposals that reward nonresident parents who are meeting their child support obligations. See Carasso and colleagues (2008) for a review of alternative designs and Edelman and colleagues (2009) for a recent related proposal.

- Expand access to benefits that are tied to parental status. The Medicaid and CHIP programs in many states provide health benefits to children and their resident parents, but not to their nonresident parents. Expanding these benefits to nonresident fathers who are paying child support would help support their efforts to provide for their children. Similarly, families with children are often privileged in receiving access to public housing; while priority should be given to resident parents, access to stable housing could facilitate nonresident fathers' efforts to achieve economic stability and support their children.

- Provide jobs of last resort. Fathers cannot pay child support if they cannot find a job. Work is a fundamental element of the current safety net, necessitating some last-resort alternative not only for resident parents, but also for nonresident parents, including those with a history of 
incarceration. Alternative proposals for job training and public job programs are addressed by other conference authors.

Many of these programs would benefit childless adults as well as parents, and extending programs irrespective of parental status avoids potential perverse incentives (e.g., making training or benefits for disadvantaged young adults contingent on them becoming parents). Programs and benefits targeted to noncustodial parents (and not available to childless adults) should be contingent on noncustodial parents meeting their child support obligations.

A third key direction for child support policy includes innovations that respond to economic uncertainty and complex and dynamic family organization. The child support enforcement system generally works well for simple families (that is, those in which parents have had children only with each other) and those with employed nonresident parents. ARRA restored funding to support the child support enforcement system, which was essential for maintaining current efforts. Policy reforms are necessary for the system to more effectively handle the challenges associated with less stable economic opportunities and more dynamic and complex family structures.

Some child support enforcement innovations have made the system more effective in dealing with less stable employment and earnings. For example, automatic withholding and the National Directory of New Hires mean child support orders are more easily enforced when nonresident parents change employers. A difficult issue is how much child support can be expected from nonresident parents who are not working. In the past, some states have assumed a child support order could be set based on an assumption that nonresident parents could find a full-time job; this assumption is less tenable during a recession. Another difficult issue is whether (and how) child support orders should change when nonresident parents suffer earnings losses or unemployment. While it is early to assess the child support enforcement system's response to the current recession, there is evidence that child support orders generally are not responsive to changes in earnings (Ha, Cancian, and Meyer 2009). Moreover, in the absence of a system of publicly guaranteed child support, child support orders that are more responsive to changes in nonresident parents' incomes will necessarily provide less stable support to resident parents and children (Cancian and Meyer 2006b).

Finally, we note that many, if not most, parents of low-income children will be involved in complex families in which one or both parents have had children with more than one partner (Cancian, Meyer, and Cook forthcoming). Failing to consider fathers' multiple obligations substantially underestimates the challenges nonresident fathers face in meeting their economic obligations to their children (Sinkewicz and Garfinkel 2009). While alternative approaches to child support guidelines for complex families all involve difficult trade-offs (Cancian and Meyer 2006a), the issue affects too many poor children to be ignored. In the absence of a public guarantee of a minimum level of support, policymakers face the difficult task of finding the balance between fathers' limited resources and the needs of all their children.

\section{There Is Little Evidence That Policies Designed to Reduce the Proportion of Children Living in Single-Parent Families Can Substantially Reduce Poverty and Economic Distress}

Children born to unmarried parents are at greater risk of poverty, and, as just discussed, complex families resulting from births across multiple partners present particular challenges. We have outlined some strategies for responding to changes in family forms, but some would argue that these 
efforts amount to treating the symptoms rather than the underlying causes. To some extent, our approach reflects the need to respond to the current reality: 40 percent of U.S. children are born to unmarried parents, many or most of whom will have children with multiple partners. It also reflects our assessment that policies designed to shape, rather than respond to, family structure are unlikely to substantially reduce poverty, even in the long run (Cancian and Reed 2009).

Notwithstanding our assessment that the effects of policy on family formation are likely to be modest, it is noteworthy that even small changes in marriage patterns could produce substantial returns on fairly modest investments (Amato 2005; Amato and Maynard 2007). It is too early to know whether recent efforts to promote healthy marriage will be successful (Dion 2005; Dion et al. 2008); some policies to encourage marriage and, especially, reduce unplanned and teen pregnancy, may prove effective. Given the range of challenges faced by single parents, and especially by families formed by young, unmarried, and otherwise disadvantaged parents, developing appropriate contraception and relationship programs is a worthy focus for future research and evaluation, even while these programs are unlikely to substantially reduce poverty rates generally.

\section{Conclusions}

The United States has adopted a work-focused antipoverty strategy that requires policies that support both parents' efforts to work and contribute to the economic support of their children. If resident parents, especially single mothers, are to meet their obligations as parents and workers, then they need supports including child care, workplace flexibility, and, for low earners, wage supplements (e.g., the EITC) and subsidized health insurance. They also need an unemployment insurance system that recognizes that many workers who are the primary source of support for their families may also be the primary caregiver, necessitating part-time employment or temporarily leaving work to manage family responsibilities.

Enforcing the responsibility of nonresident fathers to provide for their children, and providing the supports necessary for them to work and meet their obligations, is another essential component of a work-based antipoverty strategy. Even disadvantaged fathers should be expected to support their children, and the support they pay should benefit their families, not offset government costs.

ARRA includes expanded funding for child care, a more generous EITC, and key expansions of the unemployment insurance program. It also temporarily restores a significant source of funding for child support enforcement. These changes are an important starting point for antipoverty policy supporting families, but most are time limited. While the recession highlighted the urgency of many of these programs, the needs they address are longstanding and require a sustained response. 


\section{References}

Amato, Paul R. 2005. "The Impact of Family Formation Change on the Cognitive, Social, and Emotional Well-Being of the Next Generation." The Future of Children 15(2): 75-96.

Amato, Paul R., and Rebecca A. Maynard. 2007. "Decreasing Nonmarital Births and Strengthening Marriage to Reduce Poverty." The Future of Children 17(2): 117-41.

Bureau of Labor Statistics. 2007. National Compensation Survey: Employee Benefits in Private Industry in the United States, March 2007. Washington, DC: U.S. Department of Labor. http://www.bls.gov/ncs/ebs/sp/ebsm0006.pdf.

Cancian, Maria, and Daniel R. Meyer. 2006a. Alternative Approaches to Child Support Policy in the Context of Multiple-Partner Fertility. Report to the Wisconsin Department of Workforce Development. Madison, WI: Institute for Research on Poverty.

- 2006b. "Child Support and the Economy." In Working and Poor: How Economic and Policy Changes Are Affecting Low-Wage Workers, edited by Rebecca Blank, Sheldon Danziger, and Robert Schoeni. New York: Russell Sage Foundation.

Cancian, Maria, and Deborah Reed. 2009. "Family Structure, Childbearing, and Parental Employment: Implications for the Level and Trend in Poverty." In Changing Poverty, Changing Policies, edited by Sheldon Danziger and Maria Cancian (92-121). New York: Russell Sage Foundation.

Cancian, Maria, Daniel R. Meyer, and Emma Caspar. 2008. "Welfare and Child Support: Complements, not Substitutes.” Journal of Public Policy and Management 27(2): 354-75.

Cancian, Maria, Daniel R. Meyer, and Steven Cook. Forthcoming. Evolution of Family Complexity from the Perspective of Children. Demography.

Cancian, Maria, Daniel R. Meyer, and Eunhee Han. Forthcoming. "Child Support: Responsible Fatherhood and the Quid Pro Quo." in the Annals of the American Academy of Political and Social Science.

Carasso, Adam, Harry J. Holzer, Elaine Maag, and C. Eugene Steuerle. 2008. “The Next Stage for Social Policy: Encouraging Work and Family Formation among Low-Income Men.” Tax Policy Center Discussion Paper 28. Washington, DC: The Urban Institute.

Danziger, Sheldon, and David Ratner. Forthcoming. "The Labor Market and the Transition to Adulthood." The Future of Children, special issue on "The Transition to Adulthood."

Dion, Robin M. 2005. “Healthy Marriage Programs: Learning What Works.” Future of Children 15(2): 139-56.

Dion, Robin M., Alan M. Hershey, Heather H. Zaveri, and Sarah A. Avellar. 2008. Implementation of the Building Strong Families Program. MPR Reference No. 8935-134. Washington, DC: Mathematica Policy Research, Inc. 
Edelman, Peter, Mark Greenberg, Steve Holt, and Harry Holzer. 2009. "Expanding the EITC to Help More Low-Wage Workers.” Washington, DC: Georgetown Center on Poverty, Inequality and Public Policy.

Edin, Kathryn, and Maria Kefalas. 2005. Promises I Can Keep: Why Poor Women Put Motherhood Before Marriage. Berkeley: University of California Press.

Ellwood, David T., and Christopher Jencks. 2004. "The Spread of Single-Parent Families in the United States Since 1960." In The Future of the Family, edited by Daniel Patrick Moynihan, Timothy Smeeding, and Lee Rainwater. New York: Russell Sage Foundation.

Fass, Sarah. 2009. "Paid Leave in the States: A Critical Support for Low-Wage Workers and Their Families.” New York: National Center for Children in Poverty, Mailman School of Public Health, Columbia University.

Fragile Families. 2007. "Parents' Relationship Status Five Years After a Non-Marital Birth.” Research Brief 39. Princeton, NJ: Bendheim-Thoman Center for Research on Child Wellbeing, Princeton University, and Social Indicators Survey Center, Columbia University. http://www.fragilefamilies.princeton.edu/briefs/ResearchBrief39.pdf.

Ha, Yoonsook, Maria Cancian, and Daniel R. Meyer. 2009. "Unchanging Child Support Orders in the Face of Unstable Earnings.” Madison, WI: Institute for Research on Poverty.

Ha, Yoonsook, Maria Cancian, Daniel R. Meyer, and Eunhee Han. 2008. Factors Associated with Nonpayment of Child Support. Report to the Wisconsin Department of Workforce Development. Madison, WI: Institute for Research on Poverty.

Hamilton, Brady E., Joyce A. Martin, and Stephanie J. Ventura. 2009. "Births: Preliminary Data for 2007.” National Vital Statistics Reports 57(12). Hyattsville, MD: National Center for Health Statistics.

Kaiser Commission on Medicaid and the Uninsured. 2009. "American Recovery and Reinvestment Act (ARRA): Medicaid and Health Care Provisions." Washington, DC: Kaiser Commission on Medicaid and the Uninsured. http://www.kff.org/medicaid/upload/7872.pdf.

Mezey, Jennifer, Mark Greenberg, and Rachel Schumacher. 2002. “The Vast Majority of Federally Eligible Children Did Not Receive Child Care Assistance in FY2000.” Policy report. Washington, DC: Center for Law and Social Policy.

Mishel, Lawrence, Ross Eisenbrey, John Irons, Josh Bivens, and Ethan Pollack. 2009. American Jobs Plan: A Five-Point Plan to Stem the U.S. Jobs Crisis. Washington, DC: Economic Policy Institute. http://epi.3cdn.net/c68c0d218e2750adb3_rwm6iz75b.pdf.

National Governors Association. 2009. "Child Support Enforcement.” Policy Position HHS-08. Washington, DC: National Governors Association.

Scholz, John K., Robert Moffitt, and Benjamin Cowan. 2009. “Trends in Income Support," In Changing Poverty, Changing Policies, edited by Sheldon Danziger and Maria Cancian (203-41). New York: Russell Sage Foundation. 
Sherman, Arloc. 2009. "Recovery Agreement Temporarily Expands Child Tax Credit for Large Numbers of Children in Every State." Washington, DC: Center on Budget and Policy Priorities. http://www.cbpp.org/cms/index.cfm?fa=view\&id=2547.

Sinkewicz, Marilyn, and Irwin Garfinkel. 2009. "Unwed Fathers' Ability to Pay Child Support: New Estimates Accounting for Multiple-Partner Fertility.” Demography 46(2): 247-63.

Sorensen, Elaine, and Chava Zibman. 2001. "Getting to Know Poor Fathers Who Do Not Pay Child Support.” Social Service Review 75(3): 420-34.

U.S. Department of Health and Human Services. Assistant Secretary for Planning and Evaluation. Office of Human Services Policy. 2005. "Child Care Eligibility and Enrollment Estimates for Fiscal Year 2003.” Policy issue brief. Washington, DC: U.S. Department of Health and Human Services, Assistant Secretary for Planning and Evaluation, Office of Human Services Policy. 


\section{Notes}

${ }^{1}$ Bureau of Labor Statistics, "Table A-3. Employment Status of the Civilian Noninstitutional Population by Sex and Age, Seasonally Adjusted,” http://www.bls.gov/web/cpseea3.pdf.

2 Bureau of Labor Statistics, "Employment Characteristics of Families in 2008," news release USDL 09-0568, May 27, 2009, http://www.bls.gov/news.release/archives/famee_05272009.pdf, table 5; and Bureau of Labor Statistics, "Women in the Labor Force: A Databook," http://www.bls.gov/cps/wlf-databook2009.htm, table 5 (Employment status by sex, presence and age of children, race, and Hispanic or Latino ethnicity, March 2008).

${ }^{3}$ See also Center for Law and Social Policy (CLASP), "Final Conference Agreement: American Economic Recovery and Reinvestment Act of 2009,” http://www.naeyc.org/files/naeyc/file/policy/ecwsi/FinalAgreementChart.pdf.

${ }^{4}$ CLASP, "Tracking American Recovery and Reinvestment Act Funds,"

http://www.clasp.org/issues/pages?type=child_care_and_early_education\&id=0009.

${ }^{5}$ National Association of State Workforce Agencies, “American Recovery and Reinvestment Act Resource Center," http://www.workforceatm.org/recovery/.

${ }^{6}$ Internal Revenue Service, "ARRA and the Earned Income Tax Credit," http://www.irs.gov/newsroom/article/0,id=205666,00.html.

7 U.S. Census Bureau, "Custodial Mothers and Fathers and Their Child Support: 2007, Detailed Tables," http://www.census.gov/hhes/www/childsupport/chldsu07.pdf, table 4 (Child Support Payments Agreed to or Awarded Custodial Parents by Selected Characteristics and Sex: 2007). 